\title{
Epidermolysis bullosa simplex with muscular dystrophy
}

INSERM

\section{Source}

INSERM. (1999). Orphanet: an online rare disease and orphan drug data base.

Epidermolysis bullosa simplex with muscular dystrophy. ORPHA:257

Epidermolysis bullosa simplex with muscular dystrophy (EBS-MD) is a basal subtype of epidermolysis bullosa simplex (EBS, see this term) characterized by generalized blistering associated with muscular dystrophy. 